\title{
Interspecific competition for space by hydroids and a sea anemone living on gastropod shells inhabited by hermit crabs
}

\author{
William R. Brooks* \& Richard N. Mariscal \\ Department of Biological Science, Florida State University, Tallahassee, Florida 32306, USA
}

\begin{abstract}
The sea anemone Calliactis tricolor (Lesueur) and hydroids of the genera Hydractinia and Podocoryne rarely occur together on gastropod shells inhabited by hermit crabs. The hermit crab Pagurus pollicaris Say does not lose its anemone-transferring behavior while in hydroid-colonized shells. In choice experiments, however, $C$. tricolor (which is capable of transferring itself to shells unaided) settled much more frequently on bare shells than on shells bearing hydroids. Additionally, both the sea anemones and hydroids retracted their tentacles and polyps, respectively, after contacting each other This study indicates that the negative association between these sea anemones and hydroids on gastropod shells is the result of direct avoidance of each other, presumably caused by discharged nematocysts.
\end{abstract}

\section{INTRODUCTION}

Gastropod shells of hermit crabs represent an important attachment substrate for epifauna in many predominantly soft-bottom benthic communities. Jensen \& Bender (1973) found over 59 genera representing animals from 10 phyla either in or on the shells of the hermit crab Pagurus bernhardus. Some common epifaunal organisms include bryozoans (Samuelson 1970, Jensen \& Bender 1973), gastropods of the genus Crepidula (Conover 1976, 1979, Stachowitsch 1977, 1980, Karlson \& Cariolou 1982, McLean 1983), hydractiniid hydroids (e.g. Hydractinia) (Schifjsma 1935, Crowell 1945, Conover 1976, 1979, Mills 1976a, b), and sea anemones of the genus Calliactis (Ross 1960, 1967. 1980, Mariscal 1972, Brooks \& Mariscal 1985).

Because of the small size (and area) of most gastropod shells, however, interspecific competition for space, either by exploitative or interference mechanisms, may commonly occur. For example, Karlson \& Cariolou (1982) found that, out of 381 shells with either Hydractinia echinata or Crepidula convexa, only 1

\footnotetext{
- Present address: Department of Biology, Auburn University at Montgomery, Montgomery, Alabama 36193, USA
}

shell had both organisms simultaneously. They suggest that $H$. echinata is competitively superior to $C$. convexa. Karlson (1978) has suggested that $H$. echinata inhibits overgrowth and larval settlement, and, through vegetative growth, it is able to spread over the shell surface. It is not known whether Hydractinia's cnidae also contributed to this negative association with C. convexa. However, Karlson (1981) suggests that predation by Hydractinia on the larvae of Crepidula might also be a contributing factor

Hydractinia rarely co-occurs with another epifaunal species, the sea anemone Calliactis tricolor. McLean (1983) found that only 17 out of 584 (4\%) shells collected in the northern Gulf of Mexico contained both the sea anemone and the hydroid simultaneously. One possible explanation for this negative association is that the cnidarians may prevent each other from settling on the shell by discharging their nematocysts. Another possibility is that the hermit crab's anemone transfer behavior (cf. Ross 1960) is altered by its living in a hydroid-colonized shell.

The present study was conducted to test the aforementioned hypotheses. The results indicate that nematocyst discharge following physical contact by the 2 cnidarians is the major factor contributing to their negative association in the field. 


\section{MATERIALS AND METHODS}

The hermit crab Pagurus pollicaris Say was collected in St. Joseph Bay, Florida, in the northeastern Gulf of Mexico, at depths of less than $2 \mathrm{~m}$. In this region, Pagurus pollicaris commonly inhabits the shell of the gastropod Polinices duplicatus (Say). Both the sea anemone Calliactis tricolor (Lesueur) and the hydroids Hydractinia echinata (Fleming) and Podocoryne selena Mills commonly occur on $P$. duplicatus shells inhabited by $P$. pollicaris. All of the animals were kept in closed-system aquaria and fed Tetra Min flaked fish food and freshly hatched Artemia nauplii every 3 to $4 \mathrm{~d}$.

\section{RESULTS}

During the course of this study, 520 Pagurus pollicaris were collected in Polinices duplicatus shells. A hydroid colony was present on $303(58.3 \%)$ of these shells, and Calliactis tricolor was present on 87 $(16.7 \%)$ shells. The hydroid colony and C. tricolor, however, were found simultaneously on only 8 out of the $390(2.0 \%) P$. duplicatus shells that were inhabited by the cnidarians. None of the anemones were observed in contact with the hydroid when the two occurred together.

\section{Effect of hydroid on anemone transfers by hermit crabs}

In the first experiment, Pagurus pollicaris in Polinices duplicatus shells with greater than $50 \%$ hydroid coverage, less than $50 \%$ hydroid coverage, and no hydroids (bare shells) were placed together with a single Calliactis tricolor sea anemone for $48 \mathrm{~h}$. At the end of this period, the number of anemones on the gastropod shells was recorded (Table 1). Interestingly, in $100 \%$ of the cases where bare gastropod shells were present, C. tricolor was found on the shell inhabited by

Table 1. The number of Calliactis tricolor sea anemones occurring on Polinices duplicatus shells inhabited by the hermit crab Pagurus pollicaris at the end of $48 \mathrm{~h}$

\begin{tabular}{|lccc|}
\hline $\begin{array}{c}\text { Shell } \\
\text { category }\end{array}$ & $\begin{array}{c}\text { Total no. } \\
\text { of hermit } \\
\text { crabs }\end{array}$ & $\begin{array}{c}\text { Anemone } \\
\text { trans- } \\
\text { ferred }\end{array}$ & $\begin{array}{c}\text { Anemone } \\
\text { not trans- } \\
\text { ferred }\end{array}$ \\
\hline$>50 \%$ hydroid coverage & 8 & 1 & 7 \\
$<50 \%$ hydroid coverage & 13 & 1 & 12 \\
Bare & 15 & 15 & 0 \\
Totals & 36 & 17 & 19 \\
& & $x^{2}=28.8, p<0.001$ \\
\hline
\end{tabular}

the hermit crab after $48 \mathrm{~h}$. However, the anemone was found on only 2 out of $21(9.5 \%)$ hydroid-colonized shells after $48 \mathrm{~h}$ and in each case the anemone had settled on a bare patch on the shell (Table 1).

In an experiment designed to determine the role of a bare shell in the anemone transfer process, hermit crabs that had been in hydroid-colonized shells during the first experiment (above) were allowed to enter bare shells and the number of anemones on the bare shells after $48 \mathrm{~h}$ was recorded (Table 2 ). In this second experiment, 16 out of $21(76.2 \%)$ hermit crabs were carrying anemones after entering the bare shells (Table 2)

Table 2. A comparison of the number (after $48 \mathrm{~h}$ ) of Calliactis tricolor sea anemones occurring on Polinices duplicatus shells inhabited by Pagurus pollicaris that were first in hydroid-colonized shells and then allowed to enter bare shells. The same hermit crab individuals were used in both sets of experiments

\begin{tabular}{|lcc|}
\hline \multicolumn{1}{|c}{ Hermit crabs in: } & $\begin{array}{c}\text { Anemone } \\
\text { transferred }\end{array}$ & $\begin{array}{c}\text { Anemone not } \\
\text { transferred }\end{array}$ \\
\hline Hydroid-colonized shell & 2 & 19 \\
Bare shell & 16 & 5 \\
Totals & 18 & 24 \\
& $\chi^{2}=19.1, \mathrm{p}=.001$ \\
\hline
\end{tabular}

\section{Anemone-hydroid interactions}

In a procedure designed to reveal what factors might be responsible for the negative association of sea anemones and hydroids on the same gastropod shell inhabited by hermit crabs, a tentacular retraction index was used as a measure of the degree of stimulation or irritation provided to Calliactis tricolor by different shell surfaces (i.e. covered by living hydroids, covered by non-living hydroid perisarc, or bare). The response of the anemone to each type of shell surface was recorded as either 'no response' or 'tentacular retraction' (Table 3 ). Among the 12 different $C$. tricolor anemones tested with 4 replicates of each of the different types of shell surfaces, it was clear that the shells covered with the living hydroid produced by far the greatest number of sea anemone tentacular retractions. Contact of the anemone tentacle with the hydroid perisarc (non-living skeletal material left on the shell) and the bare shell produced correspondingly fewer tentacular retractions (Table 3). It should also be noted that, when the sea anemone tentacles contacted the living hydroids, the latter typically responded by retracting many of their polyps.

Although it is well known that Calliactis anemones can be actively transferred by hermit crabs onto their 
Table 3. A summary of the frequency of 'tentacular retractions' of 12 different Calliactis tricolor sea anemones in response to different gastropod shell surface features. Trials were conducted at $1 \mathrm{~min}$ intervals. A chi-squared analysis of the replicates was inappropriate because the expected frequency of 8 of the 12 cells was less than 5 . Because there were no significant differences between the shell replicates, the data were pooled so that they could be analyzed using the chi-squared test

\begin{tabular}{|c|c|c|c|c|c|c|}
\hline \multirow{3}{*}{ Shell surface } & \multicolumn{5}{|c|}{ Number of tentacular retractions by $C$. tricolor } & \\
\hline & & Sh & ate & & Row totals & \\
\hline & 1 & 2 & 3 & 4 & & \\
\hline Covered by living hydroid & 9 & 8 & 9 & 8 & 34 & \\
\hline Covered by non-living perisarc & 1 & 2 & 1 & 5 & 9 & \\
\hline Bare & 1 & 0 & 1 & 2 & 4 & $\chi^{2}=32.93, p<0.001$ \\
\hline
\end{tabular}

gastropod shells, some species of Calliactis (including C. tricolor) are also capable of transferring to gastropod shells in the absence of a hermit crab (e.g. see Cutress \& Ross 1969, Cutress et al. 1970). A second experiment, designed to determine whether the nature of the shell surface influenced the settling behavior of the anemone, was conducted in which 3 empty Polinices duplicatus shells, one bearing live hydroids, one bearing nonliving hydroid perisarc, and one bare, were arranged equidistant from each other in a circle around each of 50 C. tricolor anemones. Of these 50, only 18 $(36.0 \%)$ had transferred to the $P$. duplicatus shells unaided at the end of a $48 \mathrm{~h}$ period. Of the 18 anemones that completed this transfer, 14 had transferred to bare shells $(77.8 \%)\left(\chi^{2}=18.4, p<0.001\right)$, and 2 each $(11.1 \%)$ to live hydroid colonized shells (on bare patches of shell) and perisarc-covered shells.

\section{DISCUSSION}

In the present study, only 8 out of $520(1.5 \%)$ Polinices duplicatus shells bore the anemone Calliactis tricolor and a hydroid (either Hydractinia echinata or Podocoryne selena) simultaneously. McLean (1983) observed only 6 out of $225 \mathrm{P}$, duplicatus shells ( $2.7 \%)$ bearing the sea anemone and the hydroid simultaneously, which is close to the ratio observed in the present study. Interestingly, McLean (1983) found that anemones and hydroids occurred together more frequently $(5 \%)$ on Fasciolaria lilium shells. Although there may be subtle differences in the co-occurrence of the 2 cnidarians due to shell species, as previously described, the low percentages indicate a strong negative association.

The lack of co-occurrence of the 2 cnidarians on gastropod shells does not appear to be the result of changes in the behavior of the hermit crab. Although Pagurus pollicaris in hydroid-colonized shells transferred significantly fewer anemones than crabs in bare shells, when the same crabs were allowed to enter bare shells, they subsequently transferred many more anemones. The results of the present study indicate that this negative association is caused by interactions between the anemone and the hydroid. For example, in the few cases where the anemone and the hydroid occurred together on the same shell, Calliactis tricolor almost always attached to a bare patch on the shell, with a small space separating its pedal disc from the edge of the hydroid colony. In addition, both C. tricolor and the hydroids retracted their tentacles and polyps, respectively, after contacting each other. Both animals possess nematocysts in their tentacles, and both are known to repel other organisms by discharging their cnidae (cf. Ross 1971, Wright 1973, McLean \& Mariscal 1973, Fotheringham 1976). Furthermore, C. tricolor, which is known to transfer to gastropod shells in the absence of a hermit crab (Cutress \& Ross 1969), chose bare shells much more frequently than either hydroidcolonized or hydroid-skeleton shells. When $C$. tricolor did choose live hydroid-colonized shells (only twice), the anemone eventually settled on a small bare patch on the shell. It therefore seems clear that, either in anemone transfers by the hermit crab or unaided, Calliactis tricolor 'prefers' to settle on bare Polinices shells that lack either living hydroids or non-living remnants of prior colonization by hydroids.

Acknowledgements. We thank Paul Greenwood and Drs. L. Abele, W. Herrnkind, D. Thistle, and W. Tschinkel for comments and criticism of the manuscript. We also thank Dr. William Jones and the Graduate and Professional Study Fellowship Program (GPSFP) at Florida State University for financial support in the form of fellowships to the senior author. Contribution no. 1016 of the Florida State University Marine Laboratory, Turkey Point, Florida.

\section{LITERATURE CITED}

Brooks, W. R., Mariscal, R. N. (1985). Asexual reproduction by the symbiotic sea anemone Calliactis tricolor (Lesueur). Bull. mar. Sci. 36 (3): 432-435

Conover, M. R. (1976). The influence of some symbionts on the shell-selection behavior of the hermit crabs, Pagurus pollicaris and Pagurus longicarpus. Anim. Behav. 24: 191-194 
Conover, M. R. (1979). Effect of gastropod shell characteristics and hermit crabs on shell epifauna. J. exp. mar. Biol. Ecol. 40: $81-94$

Crowell, S. (1945). A comparison of shells utilized by Hydractinia and Podocoryne. Ecology 26: 207

Cutress, C. E., Ross, D. M. (1969). The sea anemone Calliactis tricolor and its association with the hermit crab Dardanus venosus. J. Zool. Lond. 158: 225-242

Cutress, C. E., Ross, D. M., Sutton, L. (1970). The associaton of Calliactis tricolor with its pagurid, calappid, and majid partners in the Caribbean. Can. J. Zool. 48: 371-376

Fotheringham, N. (1976). Population consequences of shell utilization by hermit crabs. Ecology 57: 570-578

Jensen, K., Bender, K. (1973). Invertebrates associated with snail shells inhabited by Pagurus bernhardus (L.) (Decapoda). Ophelia 10: 185-192

Karlson, R. H. (1978). Predation and space utilization patterns in a marine epifaunal community. J. exp. mar. Biol. Ecol. 31: $225-239$

Karlson, R. H. (1981). A simulation study of growth inhibition and predator resistance in Hydractinia echinata. Ecol. Model. 13: 29-47

Karlson, R. H., Cariolou, M. A. (1982). Hermit crab shell colonization by Crepidula convexa Say. J. exp. mar. Biol. Ecol. 65: 1-10

McLean, R. (1983). Gastropod shells: a dynamic resource that helps shape benthic community structure. J. exp. mar. Biol. Ecol. 69: 151-174

McLean, R. B., Mariscal, R. N. (1973). Protection of a hermit crab by its symbiotic sea anemone Calliactis tricolor. Experientia 29:128-130

Mariscal, R. N. (1972). The nature of the adhesion to shells of the symbiotic sea anemone Calliactis tricolor (Lesueur). J. exp. mar. Biol. Ecol. 8: 217-224

Mills, C. E. (1976a). The association of hydractiniid hydroids and hermit crabs with new observations from north Florida. In: Mackie, G. O. (ed.) Coelenterate ecology and behavior. Plenum Press, New York, p. 467-476
Mills, C. E. (1976b). Podocoryne selena, new species of hydroid from the Gulf of Mexico, and comparison with Hydractinia echinata. Biol. Bull. mar. biol. Lab., Woods Hole 151: $214-224$

Ross, D. M. (1960). The association between the hermit crab Eupaguris bernhardus (L.) and the sea anemone Calliactis parasitica (Couch). Proc. zool. Soc. Lond. 134: 43-57

Ross, D. M. (1967). Behavioral and ecological relationships between sea anemones and other invertebrates. Oceanogr. mar. biol. A. Rev. 5: 291-316

Ross, D. M. (1971). Protection of hermit crabs (Dardanus spp.) from octopus by commensal sea anemones (Calliactis spp.). Nature Lond. 230: 401-402

Ross, D. M (1980). Post-metamorphic life history of the symbiotic anemone Calliactis parasitica (Couch). In: Tardent, P., Tardent, R. (ed.) Developmental and cellular biology of coelenterates. Elsevier/North-Holland Biomedical Press, Amsterdam, p. 171-174

Samuelson, T. J. (1970). The biology of six species of Anomura (Crustacea, Decapoda) from Raunefjorden, Western Norway. Sarsia 45: 25-52

Schifjsma, K. (1935). Observations on Hydractinia echinata (Flem.) and Eupagurus bernhardus (L.). Archs neerl. Zool. 1: $261-314$

Stachowitsch, M. (1977). The hermit crab microbiocoensis the role of mobile secondary hard bottom elements in a North Adriatic benthic community. In: Keegan, B. F., Ceidigh, P. O., Boaden, P. J. S. (ed.) Biology of benthic organisms. Pergamon, New York, p. 549-558

Stachowitsch, M. (1980). The epibiotic and endolithic species associated with the gastropod shells inhabited by the hermit crabs Pagurus oculatus and Pagurus cuanensis. P.S.Z.N.I. Mar Ecol. 1: 73-101

Wright, H. O. (1973). Effect of commensal hydroids on hermit crab competition in the littoral zone of Texas. Nature Lond. 241: 139-140 